\title{
Integrated Disease Management of Foliar Blight Disease of Onion: A Case Study of Application of Confounded Factorials
}

\author{
Efath Shahnaz ${ }^{1}$, V. K. Razdan ${ }^{2}$, S. E. H. Rizvi ${ }^{3}$, T. R. Rather ${ }^{1}$, Sachin Gupta ${ }^{2} \&$ Muneeb Andrabi ${ }^{2}$ \\ ${ }^{1}$ Division of Plant Pathology, Sher-e-Kashmir University of Agricultural Sciences and Technology of Kashmir, \\ Shalimar, India \\ ${ }^{2}$ Division of Plant Pathology, Sher-e-Kashmir University of Agricultural Sciences and Technology of Jammu, \\ Chatha, India \\ ${ }^{3}$ Division of Economics \& Statistics, Sher-e-Kashmir University of Agricultural Sciences and Technology of \\ Jammu, Chatha, India \\ Correspondence: Efath Shahnaz, Division of Plant Pathology, Sher-e-Kashmir University of Agricultural Sciences \\ and Technology of Kashmir, Shalimar, India. E-mail: efaths@gmail.com
}

Received: June 27, 2012 Accepted: October 8, 2012 Online Published: December 13, 2012

doi:10.5539/jas.v5n1p17 URL: http://dx.doi.org/10.5539/jas.v5n1p17

\begin{abstract}
Foliar blight is an important disease of onion, proving a major bottleneck in its production. Six pathogens were found associated with the disease, viz., Alternaria alternata, A. porri, A. tenuissima, Stemphylium vesicarium, Colletotrichum circinans and Cladosporium allii-cepae. Integrated disease management of the crop was attempted using chemicals (mancozeb at $0.25 \%$ and hexaconazole at $0.06 \%$ ), bio-control agents, Trichoderma viride (Tv-1) and Trichoderma harzianum (Th-1), each at $1 \times 10^{9}$ spores $^{-\mathrm{ml}}$ and phyto-extracts (Cannabis indica and Curcuma longa, each at $10 \%$ ). Mancozeb at 0.25 per cent proved most effective in managing foliar blight of onion but was at par with hexaconazole at 0.06 per cent. Among bio-control agents used, application of T. harzianum (Th-1) resulted in lower disease intensity as compared to $T$. viride $(\mathrm{Tv}-1)$, though both were statistically at par with each other, but were significantly superior over the control. The phyto-extracts, $C$. indica and $C$. longa were ineffective in the disease management.
\end{abstract}

Keywords: foliar blight, onion, confounded factorials, disease management

\section{Introduction}

Allium cepa is an important vegetable crop in India, grown for its strong flavor and pungent odour which is mellowed and sweetened by cooking. India ranks first in terms of area, accounting for 21 per cent world area and second in production after China, with a production share of around 14 per cent. Productivity, however, is low at around $11.4 \mathrm{mt} \mathrm{ha}^{-1}$, which is lower than the world average of $17.3 \mathrm{mt} \mathrm{ha}^{-1}$. A major reason for low productivity is the diseases and pests that attack the crop during various stages of development. Among the diseases, foliar blight plays an important role in decreasing the yields. A number of pathogens have been found responsible for the disease, of which Alternaria porri, A. alternata and Stemphylium vesicarium are the most common (Gupta, Srivastava, Pandey, \& Midmore, 1994; Boff, 1996; Cova \& Rodriguez, 2003). The objective of the present study was to find the most efficient fungicide(s), phyto-extract(s) and bio-control agent(s), used either alone or in combination for the management of the disease.

\section{Material and Methods}

The pathogens associated with the foliar blight disease are Alternaria alternata, A. porri, A. tenuissima, Stemphylium vesicarium, Colletotrichum circinans and Cladosporium allii-cepae. To find the effect of fungicides, phyto-extracts and bio-control agents, six week old seedlings of onion cultivar N-53, were transplanted in plots of one square meter size in a confounded factorial randomized block design with two blocks and three replications. Manures and fertilizers were applied as per the SKUAST-J package of practices. Trichoderma viride (Tv-1) and Trichoderma harzianum (Th-1), each at $1 \times 10^{9}$ spores $^{-\mathrm{ml}}$, were applied as seed treatment and then again through root dip method. The phyto-extracts (C. indica and C. longa, each at $10 \%$ ) and chemicals (mancozeb at $0.25 \%$ and hexaconazole at $0.06 \%$ ) were sprayed as soon as the disease appeared and repeated at fifteen day intervals. Disease scoring was done at fifteen days interval on 0-5 using the following scale (Sharma, 1986): 
0 : No disease symptoms

1: Few spots towards the tip, covering less than 10 per cent leaf area

2: Several dark purplish patches, covering less than 20 per cent leaf area

3: Several patches with paler outer zone, covering up to 40 per cent leaf area

4: Long streaks, covering 75 per cent leaf area or breaking of leaves from centre

5: Complete drying of leaves or breaking of leaves from base.

The per cent disease intensity (PDI) was calculated as given below (Wheeler, 1969):

$$
P D I=\frac{\text { Total sum of numerical ratings }}{\text { Number of leaves observed } \times \text { Maximum disease rating }} \times 100
$$

The analysis was done according to the methods of Tyagi, Kathuria and Rao (1970). The equality of error mean squares for the two years was tested using F-test and accordingly pooling was done.

The treatment combinations were as follows:

$\mathrm{F}_{0} \mathrm{P}_{0} \mathrm{~B}_{0} \quad$ No treatment (control)

$\mathrm{F}_{0} \mathrm{P}_{0} \mathrm{~B}_{1} \quad$ Seed treatment followed by root dip with $T$. viride $(\mathrm{Tv}-1)$

$\mathrm{F}_{0} \mathrm{P}_{0} \mathrm{~B}_{2} \quad$ Seed treatment followed by root dip with $T$. harzianum (Th-1)

$\mathrm{F}_{0} \mathrm{P}_{1} \mathrm{~B}_{0} \quad$ Three sprays with $C$. indica

$\mathrm{F}_{0} \mathrm{P}_{1} \mathrm{~B}_{1} \quad$ Seed treatment followed by root dip with $T$. viride (Tv-1), three sprays with $C$. indica

$\mathrm{F}_{0} \mathrm{P}_{1} \mathrm{~B}_{2} \quad$ Seed treatment followed by root dip with $T$. harzianum (Th-1), three sprays with $C$. indica

$\mathrm{F}_{0} \mathrm{P}_{2} \mathrm{~B}_{0} \quad$ Three sprays with C. longa

$\mathrm{F}_{0} \mathrm{P}_{2} \mathrm{~B}_{1} \quad$ Seed treatment followed by root dip with $T$. viride (Tv-1), three sprays with $C$. longa

$\mathrm{F}_{0} \mathrm{P}_{2} \mathrm{~B}_{2} \quad$ Seed treatment followed by root dip with $T$. harzianum (Th-1), three sprays with $C$. longa

$\mathrm{F}_{1} \mathrm{P}_{0} \mathrm{~B}_{0} \quad$ Three sprays with mancozeb

$\mathrm{F}_{1} \mathrm{P}_{0} \mathrm{~B}_{1} \quad$ Seed treatment followed by root dip with $T$. viride (Tv-1), three sprays of mancozeb

$\mathrm{F}_{1} \mathrm{P}_{0} \mathrm{~B}_{2} \quad$ Seed treatment followed by root dip with $T$. harzianum (Th-1), three sprays of mancozeb

$\mathrm{F}_{1} \mathrm{P}_{1} \mathrm{~B}_{0} \quad$ Two sprays with mancozeb, one spray with $C$. indica

$\mathrm{F}_{1} \mathrm{P}_{1} \mathrm{~B}_{1} \quad$ Seed treatment followed by root dip with $T$. viride (Tv-1), two sprays with mancozeb, one spray with C. indica

$\mathrm{F}_{1} \mathrm{P}_{1} \mathrm{~B}_{2} \quad$ Seed treatment followed by root dip with $T$. harzianum (Th-1), two sprays with mancozeb, one spray with $C$. indica

$\mathrm{F}_{1} \mathrm{P}_{2} \mathrm{~B}_{0} \quad$ Two sprays with mancozeb, one spray with $C$. longa

$\mathrm{F}_{1} \mathrm{P}_{2} \mathrm{~B}_{1} \quad$ Seed treatment followed by root dip with $T$. viride (Tv-1), two sprays with mancozeb, one spray with C. longa

Seed treatment followed by root dip with T. harzianum (Th-1), two sprays with mancozeb, one spray

$\mathrm{F}_{1} \mathrm{P}_{2} \mathrm{~B}_{2} \quad$ with C. longa

$\mathrm{F}_{2} \mathrm{P}_{0} \mathrm{~B}_{0} \quad$ Three sprays with hexaconazole

$\mathrm{F}_{2} \mathrm{P}_{0} \mathrm{~B}_{1} \quad$ Seed treatment followed by root dip with $T$. viride $(\mathrm{Tv}-1)$, three sprays of hexaconazole

$\mathrm{F}_{2} \mathrm{P}_{0} \mathrm{~B}_{2} \quad$ Seed treatment followed by root dip with $T$. harzianum (Th-1), three sprays of hexaconazole

$\mathrm{F}_{2} \mathrm{P}_{1} \mathrm{~B}_{0} \quad$ Two sprays with hexaconazole, one spray with $C$. indica

$\mathrm{F}_{2} \mathrm{P}_{1} \mathrm{~B}_{1} \quad$ Seed treatment followed by root dip with $T$. viride (Tv-1), two sprays with hexaconazole, one spray with $C$. indica

$\mathrm{F}_{2} \mathrm{P}_{1} \mathrm{~B}_{2} \quad$ Seed treatment followed by root dip with $T$. harzianum (Th-1), two sprays with hexaconazole, one $\mathrm{F}_{2} \mathrm{P}_{2} \mathrm{~B}_{0} \quad$ spray with $C$. indica

Two sprays with hexaconazole, one spray with $C$. longa

$\mathrm{F}_{2} \mathrm{P}_{2} \mathrm{~B}_{1} \quad$ Seed treatment followed by root dip with $T$. viride (Tv-1), two sprays with hexaconazole, one spray with $C$. longa

$\mathrm{F}_{2} \mathrm{P}_{2} \mathrm{~B}_{2} \quad$ Seed treatment followed by root dip with $T$. harzianum (Th-1), two sprays with hexaconazole, one spray with C. longa 


\section{Analysis of Data}

The data obtained from the field trial of the confounded factorial experiment was subjected to statistical analysis which revealed that the main effects due to fungicides, phyto-extracts and bio-control agents were statistically significant during the two test years. The analysis of the pooled data of the entire study period was also on the same lines.

Data presented in Table 1 reveals that mancozeb $\left(\mathrm{F}_{1}\right)$ was superior over hexaconazole $\left(\mathrm{F}_{2}\right)$, and both the fungicides resulted in reducing the disease intensity significantly over control $\left(\mathrm{F}_{0}\right)$. Among bio-control agents, application of Trichoderma harzianum (Th-1) $\left(\mathrm{B}_{2}\right)$ resulted in lower disease intensity as compared to Trichoderma viride (Tv-1) $\left(B_{1}\right)$, though both were statistically at par with each other, but were significantly superior over control $\left(B_{0}\right)$.

Table 1. Main effects of different treatments in the integrated disease management of onion foliar blight

\begin{tabular}{|c|c|c|c|c|c|c|c|c|c|c|c|c|}
\hline \multirow{3}{*}{ Main Effects } & \multicolumn{12}{|c|}{ Per cent disease intensity at different standard weeks } \\
\hline & \multicolumn{3}{|c|}{$6 \mathrm{SW}$} & \multicolumn{3}{|c|}{$8 \mathrm{SW}$} & \multicolumn{3}{|c|}{$10 \mathrm{SW}$} & \multicolumn{3}{|c|}{$12 \mathrm{SW}$} \\
\hline & $\begin{array}{c}1^{\text {st }} \\
\text { Year }\end{array}$ & $\begin{array}{c}2^{\text {nd }} \\
\text { Year }\end{array}$ & Pooled & $\begin{array}{c}1^{\text {st }} \\
\text { Year }\end{array}$ & $\begin{array}{c}2^{\text {nd }} \\
\text { Year }\end{array}$ & Pooled & $\begin{array}{c}1^{\text {st }} \\
\text { Year }\end{array}$ & $\begin{array}{c}2^{\text {nd }} \\
\text { Year }\end{array}$ & Pooled & $\begin{array}{l}1^{\text {st }} \\
\text { Year }\end{array}$ & $\begin{array}{l}2^{\text {nd }} \\
\text { Year }\end{array}$ & Pooled \\
\hline $\mathrm{F}_{0}$ & 21.19 & 12.35 & 16.77 & 21.10 & 13.84 & 17.47 & 24.43 & 14.66 & 19.54 & 43.20 & 15.81 & 29.50 \\
\hline $\mathrm{F}_{1}$ & 17.42 & 8.27 & 12.85 & 17.63 & 9.69 & 13.66 & 20.76 & 11.11 & 15.93 & 32.19 & 12.91 & 22.55 \\
\hline $\mathrm{F}_{2}$ & 18.00 & 9.01 & 13.51 & 18.36 & 10.57 & 14.47 & 21.27 & 11.76 & 16.51 & 32.35 & 13.59 & 22.97 \\
\hline C.D. $(p=0.05)$ & 0.48 & 0.64 & 0.44 & 0.54 & 0.61 & 0.45 & 0.43 & 0.51 & 0.37 & 1.41 & 0.42 & 0.84 \\
\hline $\mathrm{B}_{0}$ & 19.83 & 10.74 & 15.29 & 19.83 & 12.28 & 16.05 & 22.99 & 13.32 & 18.16 & 38.77 & 14.80 & 26.78 \\
\hline $\mathrm{B}_{1}$ & 18.41 & 9.55 & 13.98 & 18.70 & 10.96 & 14.84 & 21.99 & 11.99 & 16.99 & 34.94 & 13.68 & 24.31 \\
\hline $\mathrm{B}_{2}$ & 18.38 & 9.35 & 13.86 & 18.56 & 10.86 & 14.71 & 21.46 & 12.20 & 16.83 & 34.04 & 13.82 & 23.93 \\
\hline C.D. $(p=0.05)$ & 0.48 & 0.64 & 0.44 & 0.54 & 0.61 & 0.45 & 0.43 & 0.51 & 0.37 & 1.41 & 0.42 & 0.84 \\
\hline $\mathrm{P}_{0}$ & 17.62 & 8.66 & 13.14 & 17.97 & 10.18 & 14.08 & 21.11 & 11.53 & 16.32 & 32.97 & 13.23 & 23.09 \\
\hline $\mathrm{P}_{1}$ & 19.54 & 10.56 & 15.05 & 19.58 & 11.98 & 15.78 & 22.80 & 13.06 & 17.93 & 37.95 & 14.55 & 26.24 \\
\hline $\mathrm{P}_{2}$ & 19.46 & 10.42 & 14.94 & 15.54 & 11.94 & 15.74 & 22.55 & 12.92 & 17.74 & 36.82 & 14.53 & 25.68 \\
\hline C.D. $(\mathrm{p}=0.05)$ & 0.48 & 0.64 & 0.44 & 0.54 & 0.61 & 0.45 & 0.43 & 0.51 & 0.37 & 1.41 & 0.42 & 0.84 \\
\hline \multicolumn{13}{|c|}{$\mathrm{F}_{1}=$ Mancozeb $(0.25 \%), \mathrm{F}_{2}=$ Hexaconazole $(0.06 \%)$} \\
\hline \multicolumn{13}{|c|}{$\mathrm{B}_{1}=$ Trichoderma viride $(\mathrm{Tv}-1)\left(1 \times 10^{9}\right.$ spores $\left.^{-1}\right), \mathrm{B}_{2}=$ Trichoderma harzianum $($ Th- 1$)\left(1 \times 10^{9}\right.$ spores $\left.^{-1}\right)$; } \\
\hline \multicolumn{13}{|c|}{$\mathrm{P}_{1}=C$. indica $(10 \%), \mathrm{P}_{2}=C$. longa $(10 \%) ;$} \\
\hline $\mathrm{F}_{0}, \mathrm{~B}_{0}, \mathrm{P}_{0}$ & ontro & & & & & & & & & & & \\
\hline
\end{tabular}

In the $6^{\text {th }} \mathrm{SW}$, lowest disease intensity (17.42 and 8.27 per cent in the first and second year, respectively), was recorded in the plots treated with mancozeb, followed by hexaconazole (18.00 and 9.01 per cent in the first and second year, respectively). The per cent disease intensity recorded in the plots treated with T. harzianum (Th-1), i.e., 18.38 and 9.35 per cent in the first and second year, respectively, was at par with T. viride (Tv-1), i.e., 18.41 and 9.55 per cent in the first and second year, respectively. Both treatments were significantly superior over control (19.83 and 10.74 per cent in the first and second year, respectively). Phyto-extracts were found ineffective in disease management with 19.54 and 10.56 per cent disease intensity with $C$. indica and 19.46 and 10.42 per cent with $C$. longa, in the first and second year, respectively. The disease recorded was even higher than that observed in the control treatment (17.62 and 8.66 per cent during the first and second year, respectively). The analysis of the pooled data of first and second year revealed that mancozeb (12.85 per cent disease intensity) was most efficacious in controlling of disease followed by hexaconazole, T. harzianum (Th-1), and T. viride (Tv-1), with 13.51, 13.86 and 13.98 per cent disease intensity, respectively.

The results of the interaction effects between fungicides, bio-control agents and phyto-extracts for the first and second year are presented in the Tables 2 and 3, respectively. The data presented in the Table 2 showed that the lowest disease intensity in the $6^{\text {th }} \mathrm{SW}$ was recorded in the interaction between mancozeb and $T$. harzianum (Th-1) 
(16.71 per cent) followed by mancozeb and T. viride (Tv-1) (16.76 per cent), in the first year. In the interaction between fungicides and phyto-extracts, the lowest disease intensity was recorded in the plots treated with mancozeb alone (15.64 per cent) followed by the plots treated with hexaconazole alone (16.06 per cent). The highest disease intensity was recorded in the plots treated with $C$. longa only (21.21 per cent).

Table 2. Interaction effects between different treatments in the integrated disease management of onion foliar blight during the $1^{\text {st }}$ year

\begin{tabular}{|c|c|c|c|c|c|c|c|c|c|c|c|c|c|c|c|c|c|}
\hline \multirow{3}{*}{\multicolumn{2}{|c|}{$\begin{array}{l}\text { Interaction } \\
\text { Effects }\end{array}$}} & \multicolumn{16}{|c|}{ Per cent disease intensity at different standard weeks } \\
\hline & & \multicolumn{4}{|c|}{$6 \mathrm{SW}$} & \multicolumn{4}{|c|}{$8 \mathrm{SW}$} & \multicolumn{4}{|c|}{$10 \mathrm{SW}$} & \multicolumn{4}{|c|}{$12 \mathrm{SW}$} \\
\hline & & $\mathrm{B}_{0}$ & $\mathrm{~B}_{1}$ & $\mathrm{~B}_{2}$ & Mean & $\mathrm{B}_{0}$ & $\mathrm{~B}_{1}$ & $\mathrm{~B}_{2}$ & Mean & $\mathrm{B}_{0}$ & $\mathrm{~B}_{1}$ & $\mathrm{~B}_{2}$ & Mean & $\mathrm{B}_{0}$ & $\mathrm{~B}_{1}$ & $\mathrm{~B}_{2}$ & Mean \\
\hline & $\mathrm{F}_{0}$ & 22.07 & 20.61 & 20.88 & 21.19 & 21.99 & 20.46 & 20.84 & 21.09 & 25.49 & 23.90 & 23.89 & 24.43 & 46.54 & 40.41 & 42.65 & 43.20 \\
\hline \multirow{4}{*}{ FXB } & $\mathrm{F}_{1}$ & 18.79 & 16.76 & 16.71 & 17.42 & 18.38 & 17.21 & 17.29 & 17.63 & 21.81 & 20.23 & 20.24 & 20.76 & 35.92 & 30.16 & 30.50 & 32.19 \\
\hline & $\mathrm{F}_{2}$ & 18.62 & 17.84 & 17.55 & 18.00 & 19.09 & 18.44 & 17.56 & 18.36 & 21.68 & 21.86 & 20.26 & 21.27 & 33.83 & 34.24 & 28.97 & 32.35 \\
\hline & Mean & 19.83 & 18.40 & 18.38 & 18.87 & 19.82 & 18.70 & 18.56 & 19.03 & 22.99 & 21.99 & 21.46 & 22.15 & 38.76 & 34.94 & 34.04 & 35.91 \\
\hline & & $\mathrm{P}_{0}$ & $\mathrm{P}_{1}$ & $\mathrm{P}_{2}$ & Mean & $\mathrm{P}_{0}$ & $\mathrm{P}_{1}$ & $\mathrm{P}_{2}$ & Mean & $\mathrm{P}_{0}$ & $\mathrm{P}_{1}$ & $\mathrm{P}_{2}$ & Mean & $\mathrm{P}_{0}$ & $\mathrm{P}_{1}$ & $\mathrm{P}_{2}$ & Mean \\
\hline \multirow{4}{*}{ FXP } & $\mathrm{F}_{0}$ & 21.15 & 21.20 & 21.21 & 21.19 & 21.51 & 20.81 & 20.97 & 21.09 & 24.56 & 24.36 & 24.36 & 24.43 & 43.35 & 43.28 & 42.96 & 43.20 \\
\hline & $\mathrm{F}_{1}$ & 15.64 & 18.39 & 18.23 & 17.42 & 15.84 & 18.37 & 18.67 & 17.63 & 19.25 & 21.95 & 21.07 & 20.76 & 28.38 & 36.32 & 31.88 & 32.19 \\
\hline & $\mathrm{F}_{2}$ & 16.06 & 19.03 & 18.92 & 18.00 & 16.55 & 19.55 & 18.98 & 18.36 & 19.51 & 22.08 & 22.21 & 21.27 & 27.18 & 34.25 & 35.62 & 32.35 \\
\hline & Mean & 17.62 & 19.54 & 19.45 & 18.87 & 17.97 & 19.58 & 19.54 & 19.03 & 21.11 & 22.79 & 22.54 & 22.15 & 32.97 & 37.95 & 36.82 & 35.91 \\
\hline
\end{tabular}

$\mathrm{F}_{1}=$ Mancozeb $(0.25 \%), \mathrm{F}_{2}=$ Hexaconazole $(0.06 \%) ;$

$\mathrm{B}_{1}=$ Trichoderma viride $(\mathrm{Tv}-1)\left(1 \times 10^{9}\right.$ spores $\left.^{-1}\right), \mathrm{B}_{2}=$ Trichoderma harzianum $($ Th- 1$)\left(1 \times 10^{9}\right.$ spores $\left.^{-1}\right)$;

$\mathrm{P}_{1}=$ C. indica $(10 \%), \mathrm{P}_{2}=$ C. longa $(10 \%)$;

$\mathrm{F}_{0}, \mathrm{~B}_{0}, \mathrm{P}_{0}=$ Control; C. D. $(\mathrm{p}=0.05)$ for interaction effects F X B and F X P;

$6^{\text {th }} \mathrm{SW} 0.59,8^{\text {th }} \mathrm{SW} 0.66,10^{\text {th }} \mathrm{SW} 0.53,12^{\text {th }} \mathrm{SW} 1.72$.

Table 3. Interaction effects between different treatments in the integrated disease management of onion foliar blight during the $2^{\text {nd }}$ year

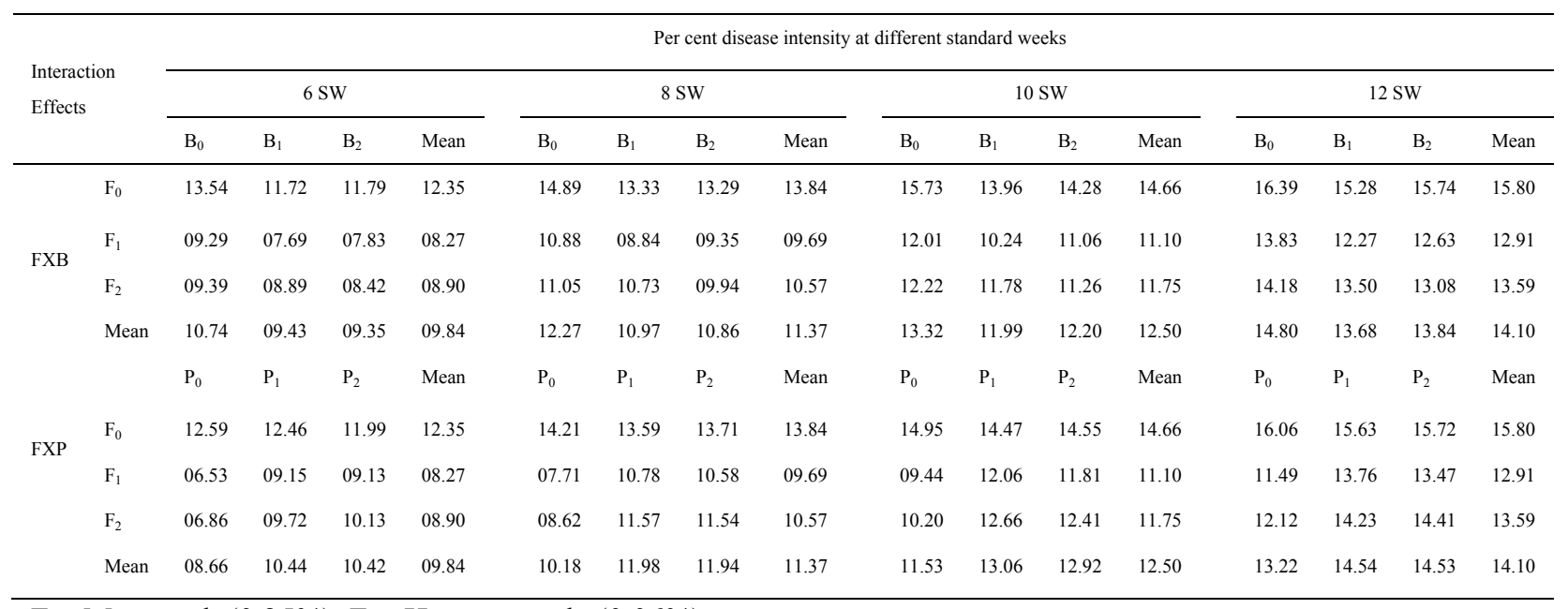

$\mathrm{F}_{1}=$ Mancozeb (0.25\%), $\mathrm{F}_{2}=$ Hexaconazole $(0.06 \%)$;

$\mathrm{B}_{1}=$ Trichoderma viride $(\mathrm{Tv}-1)\left(1 \times 10^{9}\right.$ spores $\left.^{-1}\right), \mathrm{B}_{2}=$ Trichoderma harzianum $($ Th- 1$)\left(1 \times 10^{9}\right.$ spores $\left.^{-1}\right)$;

$\mathrm{P}_{1}=$ C. indica $(10 \%), \mathrm{P}_{2}=$ C. longa $(10 \%)$;

$\mathrm{F}_{0}, \mathrm{~B}_{0}, \mathrm{P}_{0}=$ Control; C. D. $(\mathrm{p}=0.05)$ for interaction effects F X B and F X P;

$6^{\text {th }} \mathrm{SW} 0.79,8^{\text {th }} \mathrm{SW} 0.75,10^{\text {th }} \mathrm{SW} 0.62,12^{\text {th }} \mathrm{SW} 0.52$. 
In the second year, lowest disease intensity was recorded in the interaction of mancozeb and T. viride (Tv-1) (7.69 per cent) which was followed by mancozeb and T. harzianum (Th-1) (7.83 per cent) and hexaconazole and $T$. harzianum (Th-1) (8.42 per cent) in the $6^{\text {th }} \mathrm{SW}$. The highest disease intensity was recorded in the plots that received neither fungicides nor treatment with bio-control agents (13.54 per cent). Among the interaction of fungicides and phyto-extracts, the disease intensity was lowest in the plots treated with mancozeb only ( 6.53 per cent), which was at par with the plots treated with hexaconazole only ( 6.86 per cent). The highest disease intensity was recorded in the plots that did not receive any fungicide (12.59 per cent).

\section{Discussion}

Mancozeb (at $0.25 \%$ ) proved most effective in managing foliar blight of onion with disease intensity of 32.19 and 12.91 per cent in the first and second year, respectively. However, mancozeb was at par with hexaconazole (at $0.06 \%$ ) in which disease intensity of 32.35 and 13.59 per cent was recorded during first and second year, respectively. The efficacy of mancozeb in the control of foliar blight of onion has also been reported by Gupta Srvastava and Shrma (1996) and Vijaya and Rahman (2004). Among the bio-control agents, Trichoderma viride (Tv-1) proved most efficacious with disease intensity of 34.94 and 13.68 per cent in the first and second year, respectively. It was followed by T. harzianum (Th-1) with a disease intensity of 34.04 and 13.82 per cent, respectively. T. harzianum has been found effective against Alternaria brassicicola and Alternaria raphani (Vannaci \& Harman, 1987), whereas, B. subtilis has been reported to be effective against A. porri (Tajeda et al., 1998). Jeyalakshmi and Seetharaman (1998) have reported the efficacy of T. harzianum and B. subtilis for the control of Colletotrichum capsici. However, there were no prior comparative studies of fungicides and bio-control agents for the control of foliar blight of onion. The lower disease control achieved by bio-control agents as compared to fungicides might be due to adverse environmental conditions causing their rapid desiccation. $T$. viride was found to increase germination of onion seed (Srivastava \& Tiwari, 2003) and total plant stand (Champavat \& Sharma, 2003). Extract of $C$. indica (disease intensity 37.95 and 14.55 per cent in the first and second year, respectively) proved at par with $C$. longa (36.82 and 14.53 per cent, respectively) in the control of foliar blight among phyto-extracts, though both were ineffective in disease management as compared to control.

\section{Acknowledgement}

The authors duely acknowledge the help, software and invaluable guidance provided by Dr. Seema of the Indian Statistical Research Institute, New Delhi.

\section{References}

Boff, P. (1996). Survey of onion pathogens in Santa Catrina State, Brazil. Fitopatologia Braseileira, 21, 110-114.

Champawat, R. S., \& Sharma, R. S. (2003). Integrated management of nursey diseases in brinjal, chilli, cabbage and onion. Journal of Mycology and Plant Pathology, 33, 290-291.

Cova, J., \& Rodriguez, D. (2003). Fungi associated with leaf blight of onion (Allium cepa L.) in Lara State, Venezuela. Bioagro, 15, 157-163.

Gupta, R. P., Srivastava, K. J., Pandey, U. B., \& Midmore, D. J. (1994). Diseases and insect pests of onion in India. Acta Horticulturae, 358, 265-269.

Gupta, R. P., Srivastava, P. K., \& Sharma, R. C. (1996). Chemical control of purple blotch and Stemphylium diseases of onion. Newsletter National Horticultural Research and Development Foundation, 16, 14-16.

Jeyalakshmi, C., \& Seetharaman, K. (1998). Biological control of fruit rot and die-back of chilli with plant products and antagonistic micro-organisms. Plant Disease Research, 13, 46-48.

Sharma, S. R. (1986). Effect of fungicidal sprays on purple blotch and bulb yield of onion. Indian Phytopathology, $39,78-82$.

Srivastava, K. J., \& Tiwari, B. K. (2003). Nursery disease management in onion with biocontrol and plant products. Newsletter National Horticultural Research and Development Foundation, 23, 5-8.

Tajeda, G., Lopez, M., Cartellanos, J. J., Rodriguez, J., Sinanca, M. E., Crocha, G., ... Foga, S. (1998). Bench scale bioreactor production of Bacillus subtilis for the control of phytopathogenic fungi and bacteria. Fitopatogenas Revista, JCIDCA Sobre Los Derivados de Lacana de Azucar, 323, 1-6.

Tyagi, B. N., Kathuria, O. P., \& Rao, P. P. (1970). The analysis of groups of experiments involving several factors. Journal of Indian Society of Agricultural Statistics, 22, 27-42.

Vannacci, G., \& Harman, G. E. (1987). Biocontrol of seed borne Alternaria raphani and Alternaria brassicicola. Canadian Journal of Microbiology, 33, 850-856. http://dx.doi.org/10.1139/m87-149 
Vijaya, M., \& Rahman, M. A. (2004). Efficacy of fungicides in the control of leaf blight disease of onion (Allium cepa). Journal of Mycology and Plant Pathology, 34, 654-655.

Wheeler, B. E. J. (1969). An Introduction to Plant Disease (p. 301). London: John Wiley. 